Volume 7 Issue 1, March 2020

Nationally Accredited Journal,

Decree No. B/4130/E5/E5.2.1/2019

\title{
Existence Of Notary Authorization Due To Making Authorized Loading Rights Reviewed From Law Number 2 Of 2014 About Notary Position
}

\begin{abstract}
Arpangi $^{1}$ and Satria Ardi Yana ${ }^{2}$
Abstract. In its development in terms of making the Deed of Granting Mortgage or APHT the debtor can not be present which is then represented by his representative, the consequences of the debtor's representative then the APHT must be made with SKMHT or Power of Attorney Imposing Mortgage Rights. The SKMHT is made by a notary public. But in its development based on Article 96 PMNA / Per.Kaban No. 3 of 1997 as amended by Regulation No. 8 of 2012 requires that the deed is made in accordance with the form or form made by the BPN or the Land Agency, even though it is clear that it has contradicted the provisions related to the deed according to Article 15 paragraph (1) of Law Number 2 of 2014 is not quite right, this is because The notary is authorized to make an authentic deed, not to make a letter, or fill in blanks, such as SKMHT where the manuscript is made by BPN. So it is clear that the current SKMHT has contradicted the provisions referred to in Article 15 paragraph (1) of Law Number 2 of 2014. The type of research in this writing is sociological juridical. The data collection techniques in scientific research is to use literature study techniques and direct interview studies with informants in collecting and compiling the data needed. This research is a descriptive qualitative analytical research which is a study with data analysis techniques in the form of describing, analyzing, explaining, and analyzing a legal problem that occurs.

Keywords: Authentic Deed, Existence; Notary; Power of Attorney; Letter of Mortgage Right
\end{abstract}

\section{Introduction}

In its development, notaries often make SKMHT (Power of Attorney Delegating Mortgage Rights) using a form prepared by the National Land Agency (BPN), this is because if the SKMHT making does not use the form and format provided, the existing SKMHT will not be accepted by BPN. This clearly contradicts the provisions of Article 15 paragraph (1) of Law Number 4 of 1996 which explicitly states that the SKMHT is made by a Notary Public, for which there is no requirement for a BPN form to declare the SKMHT valid or not. Then by simply filling in the blank / SKMHT form provided by the BPN, the Notary does not make an authentic deed, but rather makes a letter that cannot be notarized as an authentic deed.

Basically, regarding the status of the SKMHT form made by BPN is affirmed in the provisions related to the guidelines for filling out the blank / SKMHT form as regulated in Article 96 paragraph (1) PMNA / Per.Kaban No. 3 of 1997 as amended by Regulation No. 8 of 2012, while Per. Kaban No. 8 of 2012 hierarchically, national legal regulations are under Law No. 2 of 2014 concerning the position of Notary Public.

In addition this is also not in line with the authority of the Notary to make an authentic deed as regulated in Article 15 paragraph (1) and paragraph (2) of Law No. 30 of 2004 as amended by Law No. 2 of 2014. In accordance with these provisions it is

\footnotetext{
${ }^{1}$ Lecturers Of Faculty Of Law, UNISSULA, Semarang email:arpangi@unissula.ac.id

${ }^{2}$ Student of Master of Law Program, Faculty of Law, Universitas Islam Sultan Agung email satriairin@gmail.com
} 
clear that the Notary is not permitted to complete the SKMHT form which is then considered to be the same as the authentic deed.

Based on the various reviews as explained above, it is clear that in the matter of making SKMHT with the draft deed that is not in accordance with Law No. 30 of 2004 as amended by Law No. 2 of 2014 has caused legal uncertainty in the formulation of SKMHT in the Mortgage law. According to Syafruddin Kalo said that, "legal certainty can be seen from two angles, namely certainty in the law itself and certainty because of the law." Furthermore Syafruddin Kalo stated that: ${ }^{3}$ Certainty in law is intended that each legal norm must be formulated with the sentences in it not containing different interpretations. The result will bring obedient or non-compliant behavior to the law. In practice many legal events arise, which when confronted with the substance of the legal norms that govern them, sometimes are unclear or imperfect resulting in different interpretations that result in uncertainty. Certainty in law is intended that each legal norm must be formulated with the sentences in it not containing different interpretations. The result will bring obedient or non-compliant behavior to the law. In practice many legal events arise, which when confronted with the substance of the legal norms that govern them, sometimes are unclear or imperfect resulting in different interpretations that result in uncertainty.

Furthermore Satjipto Rahardjo as quoted by Syafruddin Kalo said that: ${ }^{4}$ One aspect of legal life is certainty, that is, the law intends to create certainty in relations between people in society. One that is closely related to the issue of certainty is the problem from which the law originates. Certainty regarding the origin or source of law becomes important since law becomes an increasingly formal institution.

Furthermore Hurricane Husain Hasibuan and Rahmi Purnama Melati said that: ${ }^{5}$ In practice, it turns out that we can see a lot of people seeking justice, especially the weak economy, who feel they do not get legal certainty. This is because the judicial process in Indonesia is relatively long, and the costs are quite expensive, even though the purpose of establishing a court is to obtain legal certainty.

Based on the opinions of various legal experts, it is seen that the drafting of SKMHT described above has resulted in legal dualism and even disharmony of the law related to notarial deed making.

So it needs to be discussed more deeply related to "The existence of an Authentic Notary Deed in the Making of a Power of Attorney Imposing Underwriting Rights Reviewed From Law Number 2 of 2014 Concerning the Position of Notary".

Formulation of the problem : How is the current implementation of the Power of Attorney Imposing Mortgage Right? What are the problems that exist in the implementation of making Power of Attorney Imposing Mortgage right now?

\section{Research Methods}

The type of approach in this writing is sociological juridical, which is a legal approach that sees legal issues not only in legal normative issues, but also in sociological and philosophical issues in law.

\footnotetext{
${ }^{3}$ Syafruddin Kalo, "Law Enforcement that Guarantees Legal Certainty and Sense of Community Justice "quoted from http://www.academia.edu.com accessed December 8, 2016, page. 4.

${ }^{4}$ Satjipto Rahardjo, 2012, IImu Hukum, Citra Aditya Bakti, Bandung, page. 4 \& 16.

${ }^{5}$ Badai Husain Hasibuan and Rahmi Purnama Melati, "Asas Kepastian Hukum Dalam Peradilan Indonesia" quoted from http://www.amiyorazakaria.blogspot.com diakses 9 December 2016, hlm. 1.
} 
Volume 7 Issue 1, March 2020

Nationally Accredited Journal,

Decree No. B/4130/E5/E5.2.1/2019

\section{Research Results and Discussion}

\subsection{Implementation of Making Power of Attorney Imposes Current Mortgage Rights}

\subsubsection{Making Power of Attorney Imposes Current Mortgage Rights}

Power of Attorney Imposing Underwriting Rights or often called SKMHT is the granting of power of attorney from one legal subject (person / legal entity) to another legal subject (person / legal entity) (recipient of the power of attorney) to perform a particular business. Certain affairs (special powers) are, of course, carrying out or carrying out the burden of Underwriting Rights in the form of Deed of Granting Mortgage Rights (APHT). After the issuance of APHT, then it becomes the authority of the Mortgage holders (creditors) of the parties contained in the APHT to register at the Land Office. At the Land Office the registration process for Mortgage Rights is only based on the APHT by attaching the SKMHT as the basis for the APHT.

As for the making of SKMHT in addition to the Notary Public, it is also assigned to the Land Deed Making Officer or PPAT whose existence reaches the sub-district area, in order to facilitate the provision of services to those who need it. This is confirmed in Article 15 paragraph (1) of Law No. 4 of 1996 which among others states that: "Power of Attorney Imposing Mortgage Rights must be made with a notarial deed or PPAT deed ......". Based on this provision, the Notary has the authority to make SKMHT by deed. This means that the SKMHT made by the Notary must be made in the form of a deed, but in practice the making of the SKMHT deed by the Notary is the same as filling in the blank / form / form provided by the land agency. As for the form of the SKMHT, it is explicitly regulated in Article 96 paragraph (1) of the Regulation of the Minister of Agrarian Affairs / Head of the National Land Agency Number 3 of 1997 concerning Provisions for Implementing Government Regulation Number 24 of 1997 concerning Land Registration, hereinafter referred to as PMNA / Regulation No. 3 of 1997 as amended by Regulation of the Head of National Land Agency Number 8 of 2012 hereinafter referred to as Decree No. 8 of $2012 .{ }^{6}$ Based on this Article, the form of SKMHT used in the granting of HT and the procedure for filling it must be made following and in accordance with the attachment regulated in PMNA / Per.Kaban No. 3 of 1997 as amended by Regulation No. 8 of 2012. It is even emphasized in Article 96 paragraph (3) of PMNA / Per.Kaban 3 of 1997 as amended by Regulation 8 of 2012.

Then based on Article 38 UUJN, SKMHT made with a notarial deed based on Article 96 paragraph (1) Law No. 8 of 2012 (Perkaban) does not meet the requirements as a notarial deed, so that the Notary in making SKMHT cannot only refer to Article 96 paragraph (1) of the Civil Code but must also fulfill all the provisions contained in Article 38 of Law No. NN. 30 of 2004 jo. Law Number 2 of 2014 concerning the Law of Notary Position (UUJN). If the Notary continues to run the provisions of Article 96 paragraph (1) of the Civil Code in making SKMHT and ignores Article 38 of the National Position Law, the Notary has acted outside the provisions of making an authentic notarial deed, so that the SKMHT made with a notarial deed based on Article 96 paragraph (1) The statute does not meet the criteria as an authentic notary deed, and through a court procedure the parties to the SKMHT can cancel the SKMHT.

\footnotetext{
${ }^{6}$ Loc, cit.
} 
This can be seen one of them in Pemalang District, Deden Deni as the Head of Legal Relations of the National Land Agency of Pemalang Regency said that the registration of the represented mortgage responsibility was made through a Power of Attorney Bursting Underwriting Rights at a cost that is: ${ }^{7}$

- 50,000.00 IDR for mortgage rights with a value of up to 250,000,000.00 IDR;

- 200,000.00 IDR for bond rights with a value of 1,000,000,000.00 IDR;

- 2,500,000.00 IDR for mortgage rights of 10,000,000,000.00 IDR;

- 25,000,000.00 IDR for mortgages with a value of 1,000,000,000,000.00 IDR;

- 50,000,000.00 IDR for mortgage rights with a value of more than $1,000,000,000,000.00$ IDR.

In its development, according to Deden, making SKMHT uses forms that have been prepared at the BPN office which are filled in by parties who want to make SKMHT. When looking at the making of the existing SKMHT clearly there has been a disharmony between Article 38 of the Notary Position Law with Article 96 paragraph (1) of Law No. 8 of 2012. Based on the provisions of Article 1868 of the Civil Code, that an authentic deed is a deed made before or by a general official appointed for it.

Provisions made interpreted from the beginning and end of the process is the work of PPAT. Not in the context of filling in forms (blanks) by PPAT that used to occur before the issuance of Perkaban Number 8 of 2012, if related to the responsibilities of a PPAT fulfilled. If there is a procedure that is not fulfilled, and the procedure that cannot be fulfilled can be proven, then the deed by a court process can be declared as a deed that has the power of proof as a deed under the hand. If it has been domiciled like that, then the value of the proof is submitted to the judge.

Based on Article 1888 it states that the strength of a perfect proof of a deed is in its original minuta, so that the SKMHT made with a notarial deed based on Article 96 paragraph (1) of the Law does not have perfect proof of written evidence because it is not clearly determined which is the original minuta. On the other hand based on Article 1868 of the Civil Code regarding the provisions of authentic deeds, the SKMHT made with a notarial deed based on Article 96 paragraph (1) does not meet the provisions as authentic deeds, where the deed made in the form determined by the law, is made by the official authorized (Notary who should be subject to Article 38 UUJN, but subject to Article 96 paragraph (1) Law). Just imagine if the debtor understands this and slows down the process of imposing Underwriting Rights where the loan or credit has been received. As a result of this legal disharmony, laws related to SKMHT also do not have legal certainty.

This uncertainty issue has resulted in the neglect of existing legal justice. Without justice, policies and or rules are inappropriate as law. If, in law enforcement, it tends to value legal certainty or derive from its regulatory aspects, then as a legal value it has shifted the value of justice and the value of usefulness. This is because, in the most important legal certainty, the regulations themselves are in accordance with what is formulated. Likewise, when the value of expediency / usability is more prioritized, the value of expediency / usability will shift the value of legal certainty or the value of justice because what is most important for the value of usefulness is a fact whether the law is useful / useful for the community. This also applies to the time when the concern is only the value of justice, so it has an impact on the displacement of the

\footnotetext{
7 Deden Deni, Pembuatan SKMHT Di Pemalang, Personal interview with the Head of Legal Relations of BPN Pemalang Regency
} 
Volume 7 Issue 1, March 2020

Nationally Accredited Journal,

Decree No. B/4130/E5/E5.2.1/2019

value of legal certainty and expediency. This has implications, in law enforcement there must be a balance between the three values. ${ }^{8}$

Regarding justice there are various perspectives, equality based on equality, based on the principle that the law binds all people, so that the justice to be achieved is understood in the context of equality. The similarities intended here consist of numerical similarities and proportional similarities. Numerical equality is based on the principle of equality of each person before the law, while proportional equality is giving everyone what they are entitled to. Distributive justice, this is synonymous with proportional justice, where distributive justice is based on the granting of rights in accordance with the size of the service, so that in this case justice is based on equality, but in accordance with their respective proportions (proportional). Corrective justice, basically is justice that rests on the rectification of a mistake, for example if there is a mistake of someone who causes harm to others, then the person who caused the loss, must provide compensation (compensation) to the party receiving the loss to recover the situation as as a result of mistakes made. ${ }^{9}$

\subsection{Problems in making Power of Attorney encumbering mortgage rights}

In its development in the making of SKMHT, there were several problems that resulted in SKMHT not having clear legal force. Among them are:

\subsubsection{Legal Regulations}

It has been explained above that there has been a discrepancy between Article 38 of the Notary Position Law and Article 96 paragraph (1) of Law No. 8 of 2012. Article 38 of the Notary Position Law states that:

- Each Deed consists of: the beginning of the Deed or the head of the Deed; Deed body; and end or closing of the Deed.

- The beginning of the Deed or the head of the Deed contains: Title of Deed; deed number; hour, day, date, month and year; and full name and domicile of the Notary.

- The Deed Body contains: full name, place and date of birth, the contents of the Deed which is the will and desire of the parties concerned; and full name, place and date of birth, as well as job, position, position and place all of the identifying witnesses are left.

- End or closing of the Deed contains: The description of the reading of the Deed as referred to in Article 16 paragraph (1) letter m or Article 16 paragraph (7); The description of the signing and place of signing or translation of the Deed if any; The full name, place and date of birth, occupation, position, position and place of residence of each witness Deed; The description of the absence of changes that are occur in the making of the Deed or a description of the changes that can be in the form of additions, deletions, or replacements and the number of changes.

- Substitute Notary Deed and Temporary Notary Officials, in addition to containing the provisions referred to in paragraph (2), paragraph (3), and paragraph (4), also contain the number and date of appointment, and the official who appoints it.

\footnotetext{
${ }^{8}$ LBH Perjuangan, 2010, Law Enforcement That Guarantees Justice, Legal Certainty And Benefit (Case Study: Case of Minah).http://lbhperjuangan. blogspot.com/2010/10/penegakan-hukumyang-menjamin-keadilan.html, Accessed on January 4, 2020.

${ }^{9}$ LoC, cit.
} 
Meanwhile according to Article 96 paragraph (1) Law No. 8 of 2012 the forms of deed used in making the Power of Attorney Underwriting Rights consist of:

- Deed of sale \& purchase

- Exchange Deed of Exchange

- Grant Deed

- Deed of Entry into the Company

- Deed of Sharing of Common Rights

- Deed of Granting Mortgage Rights

- Deed of Granting Building Use Rights / Use Rights on Property Rights

- Power of Attorney Imposing Mortgage Rights

Meanwhile the existing SKMHT format is not in accordance with the text as intended in the provisions of Article 38 of the Notary Position Law but in the form of a form prepared by the local BPN. This clearly can lead to legal uncertainty in terms of the legal force of the deed of Power of Attorney overwriting. This uncertainty will obviously result in legal injustice due to the violation of human rights as stipulated in Article 28D of the 1945 Constitution. It also violates the Five Principles of the Pancasila.

\subsubsection{SKMHT Weakness Issues as Deed}

SKMHT Subject Issues, As for the SKMHT issues as follows:

- In Article 15 paragraph (1) of the UUHT concerning the stipulation of the time limit for the use of SKMHT to guarantee certain repayments. According to the explanation in Article 15 paragraph 1 letter (a) the UUHT demands that the power of attorney impose a mortgage right specifically made only to grant the power of attorney to charge mortgage rights only, so that it is also separate from the other deeds. The authorities impose Mortgage can no longer be united with a credit agreement, but must be made separately.

- The deadline for the application of SKMHT can cause several things: The Power of Attorney Imposes Underwriting Rights is null and void because the registration of uncertified lands takes a long process that exceeds the time limit determined by Article 15 of the UUHT; Endangering the interests of the Bank due to the stipulation of the short term is not impossible that the credit has been bad even though the new credit has not been given three months, not because the bank's analysis of business feasibility will be given is not good but the bottleneck can occur as a result of economic changes or changes in regulations that occur both abroad and within the country.

- With the obligation to make guarantee deed of Mortgage and Power of Attorney Imposing Mortgage with notary deed and followed by registration, then the obligation will definitely require additional costs that burden the debtor.

Various kinds of weaknesses from the making of the Power of Attorney Imposing Underwriting Rights as explained above clearly have resulted in legal uncertainty in the making of the Power of Attorney Imposing Rights.

\section{Closing}

\subsection{Conclusion}

- In its development based on Article 96 PMNA / Per.Kaban No. 3 of 1997 as amended by Regulation No. 8 of 2012 requires that the deed is made in accordance with the form or form made by the BPN or the Land Agency, even though it is clear that it has contradicted the provisions related to the deed according to Article 15 paragraph (1) of Law Number 2 of 2014 is not quite right, this is because The 
notary is authorized to make an authentic deed, not to make a letter, or fill in blanks, such as SKMHT where the manuscript is made by BPN. So it is clear that the current SKMHT has contradicted the provisions referred to in Article 15 paragraph (1) of Law Number 2 of 2014;

- The factors that influence the emergence of problems in making SKMHT are in the form of laws and regulations, namely in the form of disharmony between Article 38 of the Notary Position Law and Article 96 paragraph (1) of Law No. 8 of 2012, the weakness of SKMHT is the validity period of SKMHT and additional costs in making SKMHT which is also a notarial certificate;

\subsection{Suggestion}

So it is necessary to do the abolition related to the provisions of Article 96 paragraph (1) Civil Code No. 8 of 2012 which contradicts the provisions of Article 38 of Law No. 2 of 2014. In addition, the BPN needs to actively oversee the implementation of the making and application of SKMHT. And the creditors must be able to reduce the intensity of the use of SKMHT. So for that it needs to be done:

- There is a need for clarity in making SKMHT so it is hoped that the provisions relating to making SKMHT can realize preventive legal protection. Protection provided by the government with the aim to prevent before the occurrence of violations. This is contained in the legislation with the intention to prevent a violation and provide guidelines or restrictions in carrying out compliance. The clarity of statutory law status from SKMHT will be able to protect the rights of the parties involved in making agreements related to Mortgage Rights.

- In addition, the National Land Agency of the Republic of Indonesia (BPNRI) must pay attention to the general provisions for making authentic deeds before making regulations for making authentic deeds of PPAT because based on Article 1888 of the Civil Code it states that the strength of perfect proof of written evidence is on the original deed, SKMHT based on Article 96 paragraph (1) The amendment is not clearly determined which is the original minuta. In Article 1868 of the Civil Code regarding the provisions of authentic deeds, the SKMHT made with a notarial deed based on Article 96 paragraph (1) of this Law violates the provisions of an authentic deed, where the deed is made in the form determined by the law, but the law that referred to is not clear because of differences in views regarding the SKMHT regulation, namely between Article 96 paragraph (1) Relationship with Article 38 of the UUJN.

- Then in the future the creditors are able to minimize the use of SKMHT by maximizing the direct signing of APHT, where land / Mortgage Objects are outside the Notary / PPAT work area, then it is required to use Notary / PPAT services where the land / Mortgage Objects are located in order to avoid differences in views on the SKMHT Deed arrangement.

\section{Bibliography}

[1] Abdul Ghofur Anshori, 2009, Lembaga Kenotariatan Indonesia (Perspektif Hukum dan Etika), UII Press, UII Press, Yogyakarta

[2] AA. Andi Prajitno, 2010, Himpunan Peraturan Perundang-Undangan Jabatan Notaris Di Indonesia, Cetakan Pertama, Putra Media Nusantara, Jakarta

[3] Gatot Supramono, 2013, Perjanjian Utang Piutang, Kencana, Jakarta 
eISSN : 2581-2114, pISSN: 2406-9426

[4] Made Oka Cahyadi Wiguna, 2017, Surat Kuasa Membebankan Hak Tanggungan dan Pengaruhnya Terhadap Pemenuhan Asas Publisitas dalam Proses Pemberian Hak Tanggungan, Jurnal Legislasi Indonesia, Volume 14 Nomor 04, Desember 2017, Direktorat Jenderal Peraturan Perundang-undangan Kementerian Hukum dan HAM RI, Jakarta

[5] Syafruddin Kalo, "Penegakan Hukum yang Menjamin Kepastian Hukum dan Rasa keadilan Masyarakat" dikutip dari http://www.academia.edu.com diakses 8 Desember 2016

[6] Satjipto Rahardjo, 2012, IImu Hukum, Citra Aditya Bakti, Bandung

[7] Badai Husain Hasibuan dan Rahmi Purnama Melati, "Asas Kepastian Hukum Dalam Peradilan Indonesia" dikutip dari http://www.amiyorazakaria.blogspot.com diakses 9 Desember 2016

[8] Karya Gemilang, 2009, Himpunan Peraturan Perundang-undangan Jabatan Notaris dan PPAT, Indonesia Legal Center Publising, Jakarta

[9] Karya Gemilang, 2009, Himpunan Peraturan Perundang-undangan Jabatan Notaris dan PPAT, Indonesia Legal Center Publising, Jakarta

[10] Lumban Tobing, 1980, Peraturan Jabatan Notaris, Erlangga, Jakarta

[11] Gatot Supramono, 2013, Perjanjian Utang Piutang, Kencana, Jakarta

[12] Trisadini Prasastinah Usanti dan Leonora Bakarbessy, 2014, Buku Referensi Hukum Perbankan: Hukum Jaminan, Revka Petra Media, Surabaya 